\title{
Improving Students' Reading Comprehension of Narrative Text Through Cooperative Story Mapping Technique
}

\author{
Kristina Laora \\ Universitas Tanjungpura \\ kristina.laora@gmail.com \\ Gatot Sutapa \\ Universitas Tanjungpura \\ yohanes.gatot.sutapa.y@fkip.untan.ac.id \\ Regina \\ Universitas Tanjungpura \\ regina@fkip.untan.ac.id
}

\begin{abstract}
Narrative Text has been used in the National Examination of English Language for students in Junior High School in Indonesia. This research attempts to help the students in comprehending the Narrative Text especially the elements of the story, main ideas and spesific informations. This classroom action research study focuses on the use of Cooperative Story Mapping technique to improve students' reading comprehension. The subjects of the research were 27 students of class B in SMP Tarsisius. The research findings showed that students' reading comprehension enhanced through the use of Cooperative Story Mapping technique. The students actively engaged in the story mapping process. It made much easier for the students to identify the elements of the story and provided creative way for the teacher in solving the problem for teaching a narrative text. Students enjoyed reading the narrative text by using Cooperative Story Mapping. Future studies should be developed by analyzing the topic in experimental point of view so it creates an ideal learning experience.
\end{abstract}

Keywords: Reading Comprehension, Narrative Text, Cooperative Story Mapping

\section{INTRODUCTION}

Literacy has become the most potential issues in the process of teaching and learning. The demand of the curriculum in targeting reading as one important skill that must be mastered by the students in Junior High School has became an important issues in educational setting. The genre of text namely Descriptive, Narrative, Recount, Procedure and Report were included in the school curriculum. The students must be able to identify the rhetoric structures, main ideas, supporting details and spesific information. In fact, it becomes a challenge for the student of Junior High School especially in SMP Santo Tarsisius. Most of the students are Chinese descendants on which use Hakka language actively in their daily lifes. Those ethnic background has influenced their learning process. Reading ability is critical for future academic performance.

Among the fifth genre of text of Descriptive, Recount, Procedure, Narrative and Report. Narrative text has become one of the most urgent issues in SMP Santo Tarsisius due to its complexity. The complexities occur in many aspects including language barriers, reading motivation and 
appropriate teaching strategies. As an educator, the teacher plays an important role to help the students. To facilitate the development of literacy for ELLs', previous studies have attempted to integrate various techniques. Chen et all (2017) have used mobile assisted narrative reading practice for young English Language Learners from a funds of knowledge approach. The Research findings showed that ELLs' learning motivation and quality of narrative reading abilities were enhanced through the use of this mobile technology. It provided a creative ways to incorporate culture-based instructional models of learning. This study highlighted the multiliteracies education of ELLs' using technology. However, Yanguas (2009) investigates the effects that different types of multimedia glosses, namely textual, pictorial, and textual + pictorial, have on text comprehension and vocabulary learning when the goal is exclusively comprehension. The results confirm that the multimedia glosses under investigation have a different effect on comprehension and vocabulary learning respectively.

In addition, Murphy (2007) creates an online version of a reading programme, a customdesigned English language proficiency course at a university in Japan. The result showed that students performed best on a follow-up comprehension exercise when in pairs and having been provided with Elaborative feedback. Furthermore, qualitative analysis of transcribed interactions also shows that Elaborative feedback was conducive to quality interaction. In line with the literacy issues above, this study investigates the use of Cooperative Story Mapping technique to improve students' reading comprehension of Narrative text in SMP Santo Tarsisius. Cooperative Story Mapping combines the use of a story mapping strategy with cooperative learning procedures to create an activity in which students are actively engaged in analyzing and discussing stories. This technique has been introduced by Mathes et all (2007).

It is designed to promote greater reading comprehension development is students at various point along the reading achievement continuum. The use of a graphic organizer in a story map is beneficial to gain students' prior knowledge on the elements of the story. Burger (2010) found that throughout the intervention the students became more willing to work with the story mapsw and were providing more detailed information for each elements and the retelling abilities of both students increased.

The cooperative learning provides a vehicle for creating the desired learning environment. Peer work constribute positive attitude toward the learning process. Students work cooperatively to overcome certain issues to achieve the goal. It promotes peer interaction, which helps the development of language and the learning of concepts and content. Ching-Ying Pan \& Yi Wu (2013) conclude that Cooperative learning instruction created a significantly positive effect on student motivation toward learning English reading and student learning motivation, particularly in liking, dedication, self-efficacy, and extrinsic motivation. Students are trained to be more confidence in using the language due to the sharing process during the teaching and learning process. It also constributes the students motivation on reading comprehension. In cooperative story mapping, the students work together to provide an organizational framework to enhance students' interactions with stories. Therefore, to improve the students' reading comprehension, Cooperative Story Mapping is used in this research.

\section{METHOD}

This Cooperative Story Mapping employed classroom action research study as the design of the research. Based on Carr \& Kemmis, (1986) CAR is a 'self-reflective enquiry' undertaken by participants in or order to improve the rationality and justice of their own social or educational practices as well as their understanding of these practices and the situations in which these practices are carried out. This study describes how Cooperative Story Mapping improve students' reading comprehension on narrative text. The cyclical Action Research Model namely planning, acting, observing and reflecting are used as a procedure in conducting this research. The 27 eight students 
of SMP Santo Tarsisius grade VIII class B participated in this 3 months CAR project. Class B is used due to the low motivation of the students in learning especially in reading texts. The trustworthies of the data collection was gained by triangulation of the field notes, recording, focus group interview and test. Observation and measurement technique were used in obtaining the data. The result of the observation recorded in field notes. Field notes was used to describe unpredictable things on which happen during the process of teaching and learning. Recording was used to monitor the activities in the classroom. In measuring the students' performance, pre and post test were used regularly. However, In monitoring the progress, focus group interview is used with open ended questions in each cycle.

This study employed qualitative and quantitative data analysis. Data analysis refers to the process of organizing and summarizing the data into pattern and categories in such a way in order to arrive at the result and conclusion of the research (Silegar and Shohamy, 1989). In the other words, data analysis is the process of evaluating data using analytical and logical reasoning to examine each component of the data provided. Qualitative data analysis lies in the processes of describing phenomena, classifying it, and seeing how the concepts interconnect (Dey, 2012). This qualitative data was obtained through observation, field notes report and recording. Meanwhile, quantitative data generates statistics through the use of large-scale survey research, using methods such as questionnaires or structured interviews (Dawson, 2002). Tests were used to measure students' progress and performance.

The researcher chose the eighth grade students because the researcher teaches English there and the KTSP curriculum was also used. The curriculum demanded the students to be able to master all the genre of text including Narrative text. KTSP (Kurikulum Tingkat Satuan Pendidikan) or SchoolBased Curriculum (SBC) is an operational curriculum that is designed and implemented at each educational institution (school). Kusnandar (2007) states that the implementation of KTSP is a process of applying the idea, concept, and policy of the curriculum in the learning activity so the students can master some competencies.

Before choosing the sample, the researcher gave the test to class A, class B, class C. Based on the result, the students in class $\mathrm{B}$ were at the low level in comprehending the text. Therefore, Class B was chosen. Besides, the students in class B have low motivation to read the text. They didn't have courage to study and talked too much during the class. In this research, the researcher chose the reading test to measure the students' reading comprehension achievement. According to Cooper and Lewi (1988), there are seven aspects of reading comprehension including details, main idea, inference, sequence and question related to vocabulary.

The researcher applied five multiple choice questions consists of main idea, specific information, and supporting details. They also asked to fill in the story mapping sheet. The result of their of their answer was evaluated by writing rubrics dealing with aspects of narrative story namely setting, characters, problem, major events and solution. The researcher did the focused-group interview in order to know the feedback concerning the use of Cooperative Story Mapping in learning. The focused-group interview was in the form of open-ended questions. There were $2-4$ questions in each meeting depending on students' condition. The researcher asked the students' opinion about their problem in using Cooperative Story Mapping and which story elements and indicators are hard to identify.

\section{RESULTS AND DISCUSSIONS}

In the section, the researcher elaborates the result of findings and discussion from each cycle. The first part is about the results and the second is the discussions.

\section{Results}

The intervention of Cooperative Story Mapping technique to improve students reading comprehension was reported based on the procedure of Classroom Action Research both quantitatively and qualitatively. 27 students from class B participated in 3 months Classroom 
Action Research. The data were obtained from the implementation of cycle 1, cycle 2 and cycle 3. The researcher explains the data from the tools of collecting data including field notes, observation checklist, focus group interview and recording. She elaborates the data based on the research questions including the process in identifying the main idea, specific information, supporting details and elements of the story

In the first cycle, the researcher tried to elaborate the process of identifying the main ideas, spesific informations, supporting details and elements of the story of cycle one qualitatively through field notes, observation checklist and recording. At this meeting, the first local story is used and the title is "The Dragon". Here are the explanations;

Field notes - In the first meeting, the students' worked cooperatively in a group to find the main ideas, supporting details and details. During the process, the students worked with the group. Next, They read the story together silently and also discussed the difficult words. After that, They find the main ideas, supporting details, and details based on the teacher's previous explanation. Then, they presented their answer in front to have a wide class discussion. The students individual score were low. Based on the field notes, the unsatisfying result given because some of them did not understand the definition of main ideas, supporting details and details, they did it individually and they were busy to translate.

Observation checklist - In the observation, the researcher tried to observe the process of group work with four important aspects including consideration of others, contributions to the group goals, contributions' of knowledge and; working and sharing with others. The result wasn't maximal. Most of the students failed in the contributions to the group goals and the contribution of the knowledge. Based on the observation, the contribution to the group goals and the contribution of the knowledge were low because the students still rely on their friends and the teachers, some students were unfamiliar with the technique and they also played and talked during the process.

Recording - Finally, the researcher used video and photograph to describe the situation in the classroom. In this first cycle, most of them didn't concentrate well on the explanation because the technique seemed difficult for them to understand. They played with talked with their friends and did not enjoy the activity in the classroom. Unfortunately, the result of the 1 st cycle still not maximal, so it did not report the accurate data. It needs revisions. Therefore, another cycle of inquiry is urgently needed. The reflection is needed including the teacher needs to explain the materials well and also simplify the simple story map sheet.

Secondly, the researcher tried to elaborate the process of identifying the main ideas, spesific informations, supporting details and elements of the story of cycle one quantitatively through focused-group interview and the result of test. They are including;

Test - There were 5 (five) multiple choice questions given to the students with the local story entitled The Dragon. They have to read the text carefully and choose the best answers. The researcher provided questions related to main idea, supporting detail, specific information and the elements of the story. Based on the individual score below, the students' score tests were still low. There were $67 \%$ got the score for $40-60,10-20$ is about $15 \%$. Only $18 \%$ got the score around $80-$ 100. It means that the students still need improvement for the reading test relating to the text given. During the test, the students felt worry and some of them tried to cheat to the friend next to them.

Focus Group Interview - the researcher conducted focus group interview. There are 2 (two) questions for 27 students. The questions were in the form of open-ended questions on which they were free to share opinions. There were 4 up to 5 students in each group. Based on the focus group interview, most of the students were hard to understand the story and still confuse with the cooperative story mapping technique. Besides, they also had difficulties to identify the elements of the story, the main idea, supporting detail and specific information.

In cycle 2, The researcher used the story entitled Belimbing Stone and Poteng Mount. The data described qualitatively through field notes, observation checklist and recording as follows:

Field notes - At this stage, for the first, the students translated the text together. Then, they worked cooperatively to complete the story map sheet on which consist of all the indicators. Finally, they map the story. After mapping the story, the students reported their works and shared ideas to other groups. There were improvements in identifying the story elements especially major events 
and solution. It means most of the students comprehend the text easily. It is also supported by the field notes that the students could easily answer the test because they have worked together to identify all the elements stated in the story map sheet.

Observation Checklist - According to the observation checklist, the improvement can be seen clearly in the aspects of contribution of knowledge and contribution to the group goals. They reached 24\% and 25\%. This achievement is backed by field note data. The students were getting use of the technique from. They know how to do it step by step because they have given the detail guidance. They also like the simple text but still some of them were not serious to the activity because they still confuse to identify some story elements. Overall the process of group work activity in this meeting done smoothly.

Recording - The recording showed that they felt excited to join the mapping activity within the group due to the fact that they were used to the process of Cooperative Story Mapping activity. The students were actively engage in the process of group work. They worked together seriously to solve the problem. Each of them has role to solve the graphic organizer. They were guided by the researcher to fill the story map because there were still some elements of the story were difficult to identify by them. It still needs revision in terms of the story elements and the process of group work.

Thus, the process of identifying the main ideas, spesific informations, supporting details and elements of the story in the second cycle done quantitatively through focused-group interview and the result of test. They will be described below:

Focus Group Interview - In the focus group interview, the students were free to answer the 4 (four) questions. Students gave positive response toward cooperative story mapping. 70\% stated that it is easy to understand. Besides, students were also interested to do a group work because it helps them to solve the problem, share opinion and finish quickly. Meanwhile, there were still some elements on which hard to identify for instance problem, major events and main ideas were not easy to identify.

Test - Each student has improvement in the second test. Only $37 \%$ of them have got the low scores but the rest of them around 63\% have got the highest score. It is also supported by the field notes that the students could easily answer the test because they have worked together to identify all the elements stated in the story map sheet.

For the last cycle, the researcher used the story entitled Thjia House. As have been mentioned previously, the qualitative data will be described through field notes, observation checklist and recording. Here are they:

Field Notes - The process of identifying main ideas conducted very well in cycle 3 . The researcher used the story entitled "Thjia" House. In this meeting, the story interests the students' attention. In this cycle, the process of determining the main idea was easily recognized because the story is simple. At this meeting, all the students read and translate the story entitle The Legend of Thjia's House (An Old Traditional House in Singkawang). The researcher lets each group to translate and understand the text. They subsumed a wide range of reading skill such as sequencing, summarization and predicting. The researcher encouraged the students to be more active.

Next, the researcher assigned each group skimming the story to find the main ideas. After that, they complete the story map. Each of them has a role to identify the elements of the story. Finally, they discuss the story. It was led by the researcher. There was improvement in all elements. The percentages were almost balance between all elements. According to field note, the students enjoyed the text because it was short and easy to understand. There was no complicated plot structure in the text. The simple text given made the students identified it easily. They were also familiar with the technique so that they did not need extra time to finish it. In brief, the process of indentifying the main ideas, supporting detail and specific information were also optimal. Then, it showed that the cooperative story mapping made the students eager to study the narrative text. It is used effectively in the learning process.

Observation Checklist - According to observation checklist, the improvement of all the aspect in the group work gave positive feedback to the students. By using the technique, The students were not only comprehend the narrative text but also work with their friends to solve something. 
Recording - The recording showed that the students did the analysis seriously with their friends in the group. They exchanged ideas on the meaning of the text. They filled the story map sheet on which consist of main idea, supporting detail, specific information and elements of the story. They finished quickly and enjoyed in mapping process. Due to the maximum achievement, the process was end in the cycle 3 because of the significant improvements.

Lastly, the researcher tried to elaborate quantitatively the data through focused-group interview and the result of test. Focus Group - 96\% of the group were able to identify the elements of the story. They love the story because the story reflects their culture. In the other words, they were familiar with the characters' name, the setting of the story and the simple plot of the story.

Test - There were improvements on the students' scores in each cycle. Most of them were satisfied with their scores. There was only $19 \%$ for $40-60$ meanwhile $81 \%$ for $80-100$. It means that the process of this action resaerch has conducted well. It was also supported with the field notes that during the test, it took only $15-30$ minutes for the students to do the test.

\section{Discussions}

During the process, the researcher gave the treatments for the students in three cycles. In the first cycle, the researcher introduced the students with local story entitled The Dragon. The students filled the story map sheet dealing with the story. During the treatment at this cycle, the researcher found that the students faced the problem dealing with the story and the story map given. The long confusing story made them hard to identify the main ideas, specific information, and some story elements including major events, problem and conclusion. The story map sheet given was also didn't complete. As the result, the students' tests were also low. In addition, their opinions about the use of Cooperative Story Mapping were also negative. The researcher evaluated the process by doing the second cycle.

In the second cycle, to solve the problem, the researcher simplified all the story elements and the indicators in a story map sheet and also made up the new local short story entitled Belimbing Stone and Poteng Mount. As usual, the students fill in the story map designed by the researcher. The treatment process in this cycle worked well. The students were identifying the story elements easily. Unfortunately, they failed to understand the main ideas of the story. Besides, according to students' opinion, they still confused to determine the main ideas and major events. Meanwhile, the results of the tests were improved better. The researcher needed to improve students' comprehension on Narrative text maximally. Therefore, at this cycle, the researcher concluded that the students still found difficulties in comprehending the text in terms of main ideas and major events.

At the third cycle, the researcher tried to solve the problem by giving them the short and familiar local story entitled Thjia House. The students were interested with the story. As the result, students identified main ideas, specific information, supporting details and the story elements easily. The results of their tests were also amazing. The multiple choice tests were created based on the lesson plan made by the researcher on which included all the story indicators. Their opinions toward Cooperative Story Mapping were also positive. They said that Cooperative Story Mapping helped them to share the ideas and direct their attentions' to the elements of the story. The process of treatments stopped at this cycle

In the discussion, the researcher elaborated the data based on the research questions stated, as follows;

First of all, regarding to main idea becomes the first focus in this research. In the first cycle, the result of main idea was not able accumulated accurately and valid, caused of some expected condition such as students were unfamiliar with the term of main idea, how to find it in the text, unfamiliar with the technique used and also need time to translate. However, there was improvement dealing with main idea in cycle 2 and 3 because the researcher created the new local story and simplify the story map sheet. The students were able to find the main idea because the 
researcher gave them some clues of how to identify the main ideas in the text. The tips of finding the main idea given guided the students to solve their problem. As the result, the students were able to identify the main ideas correctly. They knew how to find the main idea dealt with the story entitled Belimbing Stone and Poteng Mount. They worked cooperatively in the group to find the main idea of paragraph 2. 4 of the 6 groups had mentioned the right main idea of paragraph 2. The main idea was "A beam of light came from the far away; it came down at the high speed". The main idea located at the first line of the paragraph. As supported by Davis (2005) stated that generally, the most important part of any paragraph is the main idea. This is usually the first (or sometimes the last) sentence of a paragraph, and it should give you an idea of what the entire paragraph is about. In the other words, main ideas are usually in the first sentence of the paragraph, but not always.

They may also be located within the paragraph or at the end of the paragraph. They may even appear twice at the beginning and at the end. Overall the process of identifying the main ideas didn't work well in this cycle due to the fact in the focus group interviews on which $96 \%$ had mentioned that the main ideas was difficult to identify. However, the significant improvement had revealed in the cycle 3 . The story entitled Thjia House was able to attract the students in finding the main idea.

They tried to find main idea of paragraph 2. The main idea of that paragraph is "In the twentieth century, lived a Chinese citizen named Thjia Hiap Shin. The main idea is the key concept being expressed or examined. The main idea can usually be located if you can determine what the topic is. To find the topic of a selection, it is important to find main ideas when reading (Langen and Lynn Jenkins, p. 14-37). Main ideas help readers remember important information. The main idea of a paragraph tells the topic of the paragraph. The topic tells what all or most of the sentences are about. Secondly, specific information was not accumulated accurately in the cycle 1 because students were unfamiliar with the term, they didn't know how to find it in the text and they need time to translate the text. In contrast, in cycle 2 and 3, the significant change had been made by the students. It will be illustrated in the chart below; most of them clearly mentioned the right spesific information in the story entitle Belimbing Stone and Poteng Mount.

In this second cycle, the students were given three questions related to the text, the questions are as follow: 1) What was landed in a spot? The light. 2) Why did every King must meditate in that place? Because they believed that there were several angels guard the stone; And 3) Where did the light came from? The outer space. Among 4 up to 5 groups had mentioned the right answers because specific information can be easily found in the text through scanning process. When we want to locate some specific information, we engage in the search processes that usually include scanning and skimming (Guthrie \& Kirsch, 1987). Skimming as a process of speed reading that involves visually searching the sentences of a page for clues to meaning.

Next, the improvement also showed in the cycle 3. For the third story entitled Thjia House, the researcher gave 3 questions. The questions are; 1) Why did Hiap Shin try to find new job? He went bankrupt 2) Who is Akhiong? The owner of the grocery store; And 3) What did Hiap Shin build? Some houses. The students answered easily because they identified the keyword in each questions. In line with Beale (2013), she suggested to keep the concept of key words in mind while scanning. Key words can help to read more efficiently. This is helpful because the texts are quite long and normally complex. We can read more quickly by only looking at the part of the text you need to.

Therefore, dealing with specific information, there were also improvements in cycle 2 and 3. The improvements made because the researcher chose the simple short local story on which easy to understand. The models of questions given were also simple.

Thirdly, supporting details are also become one of the question that must be answered in this research. In the cycle 1, the processes of identifying the supporting details were not valid enough. 
The unexpected conditions came from the students such they didn't understand the definition of supporting detail, they didn't know how to find it in the text, less time given and many others unexpected conditions during teaching and learning process. Surprisingly, in cycle 2 and cycle 3, the improvements were seen clearly. In the second meeting in the story entitle Belimbing Stone and Poteng Mount, the students clearly included most of the relevant supporting details of paragraph 2.

The improvement in cycle 2 and cycle 3 were also proven well. The researcher gave the students hints of how to identify the supporting details in the text. They knew about the supporting details because the supporting details support the main idea. The researcher simplified the story to help the students understand the location of the supporting details in each paragraph.

Finally, in terms of story elements, the researcher had conducted the process from cycle 1 to 3 with the three different local stories. Based on the first story in the first cycle entitled The Dragon, Based on the result regarding to the story elements, the students failed to identify problem (22\%), major events (11\%) and solution (10\%) because of the following factors;

1) Partial information about the problem stated e.g. the people killed the dragon.

2) The story events were listed but there was no significant and sequential orders i.e.

a) They tried to kill the dragon. They bring knifes, guns, and some dangerous things to kill it.

b) Moreover, the leadership there also accepted the presence of the Dragon with a joy because he believed that the town will be famous and many outsiders will come and see the dragon.

c) Some people were afraid and they had intention to repel the dragon from the town.

d) They made a plan to ask the dragon to get out from the town. They gathered together to decide how to stop it

e) When they arrived at the place, the dragon is protected by large number of people whom agreed with the presence of the dragon. But luckily, they won the fight againts the small number of people whom disagree

3) They only stated the solution but didn't give detail information e.g. people couldn't see the head and only showed his long and big body.

After the students mapping all the story elements, the individual test was also low around $82 \%$ got the low score. Next, in the second cycle for the story entitled Belimbing Stone and Poteng Mount, there were improvements in terms of major events from $11 \%$ to $21 \%$ and solution from $10 \%$ to $22 \%$. The improvement had increased because of some factors:

1) Partial information about the characters e.g. some groups has mentioned an ark or giant stone became the characters in the story.

2) For the setting, their answered were varied. Most of them stated limited description of place i.e. South China Sea

3) For the problem, the students gave partial information about the problem i.e. the light came down at the high speed.

At this stage, the students achievements on the story elements were relatively increase in terms of major events and solution. Besides, the students were lack with writing ability. Moreover, the text used unclear plot and used some difficult vocabularies. The chosen story should be at an appropriate level for the weaker readers in the class. Furthermore, to enhance initial understanding of the story grammar strategy, teachers are encouraged to choose texts in which all the story elements are easy to identify (Mathes et all, 1997). The chosen story may be affected the students' understanding. In the third cycle, the researcher used the story entitled Thjia House. The result of story elements and their relationship were almost perfect due to the following facts as follows;

1) $21 \%$ had mentioned the right characters. The characters in the story are: Akhiong (the owner of the shop), Hiap Shin and Chi Liong

2) $20 \%$ had stated the right setting. The setting of the story is Singkawang.

3) $21 \%$ clearly stated the problem as it relates to the characters and included additional details. The problem in the story is: Chi Liong (one of the Akhiong's staff) was jelous to Hiap Shin and he tried to kill him with poison because Akhiong trusted him to do all the works.

4) $18 \%$ elaborated the story events significantly and sequentially. The major events included; 
a) In the 20th century, lived a Chinese citizen named Thjia Hiap Shin. He came to Borneo to trade but he went bankrupt

b) One of the staff named Chi Liong was jealous of him and tried to kill him with poison but he failed to kill him.

c) Time passed by, because of his efforts, Hiapshin had much money. He built a fleet of ships. 5) $20 \%$ stated the detailed information about the solution and how it relates to the characters. The solution in the story is; Hiap shin became rich. Then, he got married with local woman and started his new life. The seven generations live in that house until today. That house becomes the oldest house in Singkawang.

During the process, the students felt excited to the work. There was no complicated plot structure in the text and they were familiar with the characters' name given. They did the story map quickly and they could easily identify all story elements. Besides, the students filled the story map dealing with main ideas, supporting details and specific information. Boulineau et al. (2004:106) state that Story Mapping is "an intervention to direct students' attention to relevant elements of stories, such as setting, problem, goal, events, or actions that contribute the goal, the outcome or resolution of each passage, and the theme, using specific structure through visual spatial display for key information in a narrative text"

Therefore this technique is effective to direct students' attention of elements of the story. Overall, Cooperative Story Mapping technique had improved students' understanding of main idea, specific information, supporting details and the story elements. By filling the graphic organizers, the students direct their attention to the elements of the story. By working in group, they also share their knowledge and experience in understanding the narrative text. In addition, the individual scores were also obtained to know each students progress cycle to cycle. These individual tests were given at the end of the meeting in each cycle. The researcher used score from $0-100$ to measure the students ability. In cycle 1 , there were $15 \%$ of students got the score from $0-20$. In cycle $2,63 \%$ got the score from $80-100$. In cycle 3, $81 \%$ got the score from $80-100$. It can concluded that the students score were increase in which $81 \%$ of them understand the content of the story. It can be concluded that the students score were increase in which $81 \%$ of them understand the content of the story. It means that the Cooperative Story Mapping is successful. It is also because the researcher had outlined the topic, the main ideas were explained, and the essential supporting details were also developed. Meanwhile, dealing with the process of group work described as follows;

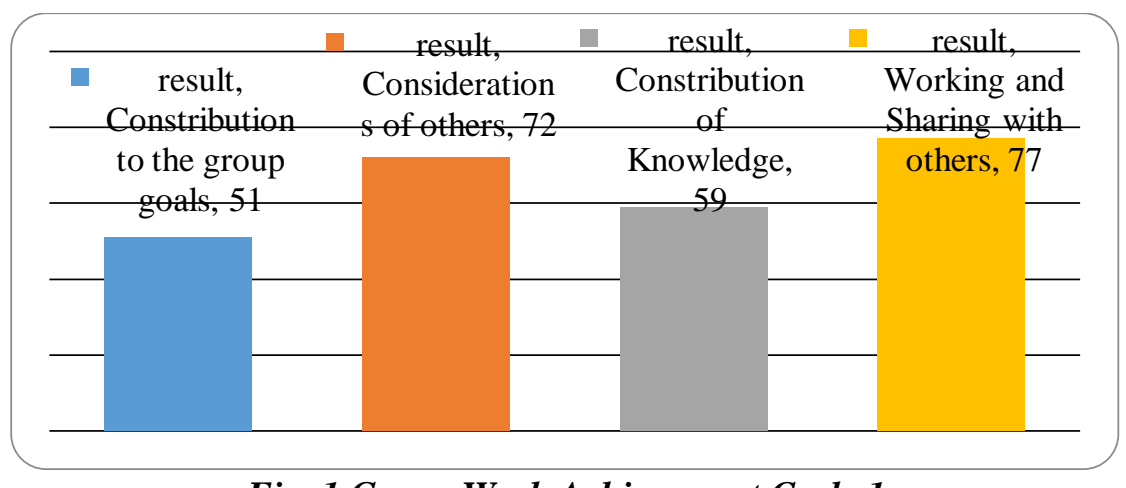

Fig. 1 Group Work Achievement Cycle 1

From the above the contributions to the group goal was only reach $51 \%$ because most of the students didn't realize the purpose of cooperative story mapping, they felt lazy to read, they depended on their friends to do the work, they blamed each others and some students didn't serious; they played and talked during the process.

In brief, all the process in cycle 1 didn't maximally achieved because the students needed adaptation with the process. Therefore the researcher continued the process to the next cycle. 
Relating to the group work, at the second cycle, the process of group work was maximally achieved. It was proven with the following chart;

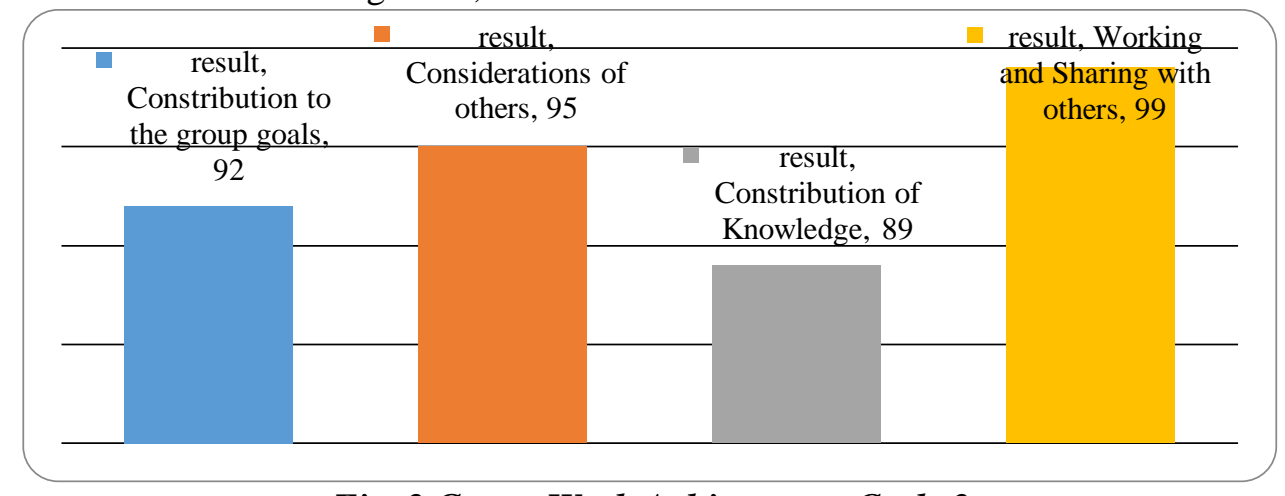

Fig. 2 Group Work Achievement Cycle 2

The chart showed us that all of the aspects had increased. However, in this stage, the contribution of knowledge was low 89\%. This happened because the students confused with the story on which the plot of the story was unclear. It made some students in the group lazy to read and share knowledge to their friends because they didn't confidence with their answer and sometimes they need teacher's assistance to solve the problem. Finally, Dealing with cooperative work, the following cycle displayed the process of group work in cycle 3 ;

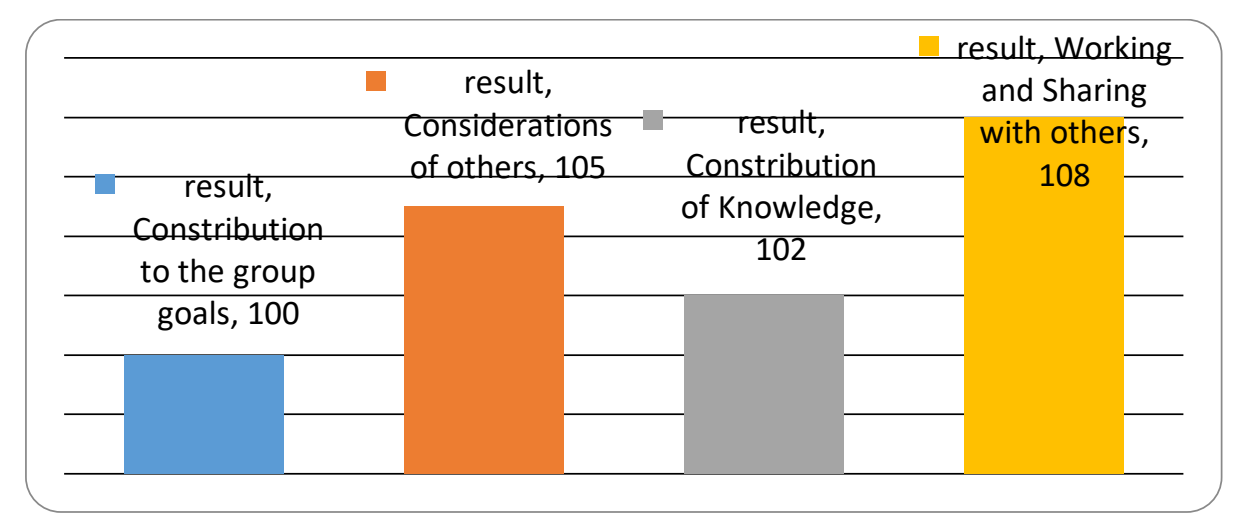

Fig. 3 Group Work Achievement Cycle 3

Based on the figure above, the students' progress can be seen in the improvement of all aspects in cycle 3. The improvement happened because the researcher controlled the process of group work in each cycles. The researcher motivated the students to work together to solve the problem. The researcher also gave reward for students whom actively engage in the process of the group work. The students felt interested because the process of teaching and learning became more enjoyable. By working in group, the students try to help each other to solve the certain problem together to achieve the goal. In addition, Chappell (2014) said that when learners working in groups, have a shared perspective of the goal-oriented classroom activity, there is a potential for collective thinking, joint construction of knowledge and scaffolding during semiotically mediated activity.

To sum up this research, the researcher concluded that Cooperative Story Mapping had opened the students' mind that Narrative text is enjoyable to study. By filling the graphic organizers in the group, they share informations; they exchange knowledge and support each others. Cooperative Story Mapping provides students a common knowledge base and a forum for them to share their interpretation of narrative text, while extending their own understanding (Mathes, 1997). The result of Cooperative Story Mapping gives positive attitude to both teacher and students. 


\section{CONCLUSION AND SUGGESTION}

Using Cooperative Story Mapping enables students to improve Reading Comprehension on Narrative text. The improvements from each cycle had proven that Cooperative Story Mapping is effective to improve students' reading comprehension. It improves students' reading comprehension on the main ideas, specific information and elements of the story.

By filling the graphic organizers in a group, it helped the students to organize narrative structure in a narrative text. Furthermore, within the modification of local stories and graphic organizers, the results indicate that the students were enjoyed to read a narrative text. In addition, The researcher provides some useful suggestions to be considered for the future research, It is suggested that educators or teachers may socialize or introduce the Cooperative Story Mapping technique in their teaching to students especially narrative text and focus on different elements to be analyzed using the technique especially for low-achieving students.

\section{REFERENCES}

Burger, A. J. (2010). Story Mapping to Support Struggling Readers and Writers with Behavioral Concerns. Education Masters. Paper 66.

Burns, A. (2010). Doing Action Research in English Language Teaching. New York: Routledge.

Carr, W., \& Kemmis, S. (1986). Becoming Critical: Education. Knowledge and Action Research. London: Falmer.

Chappell, P. (2014). Group Work in the English Curriculum Sociocultural and Ecological Perspectives on Second Language Classroom Learning. New York: Palgrave Macmillan.

Chen, Y., Carger, L C., Smith, J. T. (2017). Mobile-Assisted Narrative Reading Practice for Young English Language Learners From A Funds of Knowledge Approach. Language Learning and Technology, Volume 21, Number 1 pp. 28-41.

Davis, M. (2005). Scientific papers and presentations. London: Elsevier.

Dey, I. (1993). Qualitative Data Analysis: A User-Friendly Guide for Social Scientists. New York: Routledge.

Mathes, P. G. (1997). Cooperative Story Mapping. Remedial and Special Education, 18, 20-27.

Murphy. (2007). Reading Comprehension Exercise Online. The Effect of Feedback, Proficiency and Interaction. Language Learning \& Technology. Volume 11, Number 3 pp. 107-129.

Kusnandar. (2007). Guru Profesional. Jakarta: PT Raja Grafindo.

Pan Ching-Yin, Wu Hui-Yi. The Cooperative Learning Effect on English Reading Comprehension and Learning Motivation. Journal of English Language Teaching Vol. 6.

Yanguas I. (2009). Multimedia Glosses and Their Effect on L2 Text Comprehension and Vocabulary Learning. Language Learning \& Technology, pp. 48-67. 